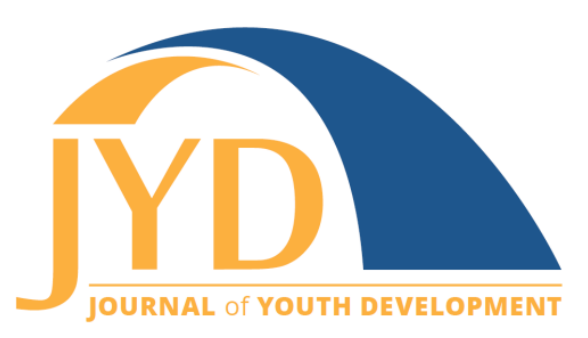

http://jyd. pitt. edu/ | Vol. 14 Issue 4 DOI 10.5195/jyd.2019.749 | ISSN 2325-4017 (online)

\title{
Using Experience Industry Strategies to Increase Quality of Youth Program Experiences
}

\author{
Allen S. Taggart \\ University of Idaho Extension \\ taggart@uidaho.edu

\section{Gary D. Ellis} \\ Texas A\&M University and Texas A\&M Agrilife Research \\ gellis1@tamu.edu \\ Jingxian Jiang \\ Texas A\&M University \\ kellyjiang@exchange.tamu.edu

\section{Andrew Lacanienta} \\ California Polytechnic State University, San Luis Obispo \\ alacanie@calpoly.edu
}

\begin{abstract}
We evaluated 4 "experience industry" strategies for enhancing the quality of immediate experiences for 4- $H$ youth: theming, adding multisensory experiences, personalizing interactions, and providing memorabilia. These strategies are commonly used by theme parks, restaurants, resorts, attractions, and other experience industry organizations, but their application to youth services is sporadic. 4-H youth (n $=30$ ) participated in a series of 8 outdoor recreation activity sessions. Each activity session, 1 per week for 8 consecutive weeks, was structured using a unique combination of the 4 strategies. Participants completed questionnaires measuring 5 dimensions of experience quality after each activity session. Theme and personalization of experiences were found to significantly increase experience quality.
\end{abstract}

Key words: youth program quality, experience, theme, 4- $\mathrm{H}$, engagement

The quality of immediate experiences of youth in meetings, events, and activities is a key to the success of youth programs. Meetings, events, performances, and competitions that youth find engaging, immersive, and valuable build commitment for continued participation. Continued

(c) $\mathrm{EY}_{\mathrm{EY}}$ New articles in this journal are licensed under a Creative Commons Attribution 4.0 License. This journal is published by the University Library System, University of Pittsburgh and is cosponsored by the University of Pittsburgh Press. The Journal of Youth Development is the official peer-reviewed publication of the National Association of Extension 4-H Agents and the National AfterSchool Association. 


\section{Quality of Experience}

intensity, duration, and breadth of participation can reduce risk factors and build key developmental outcomes (Bowers et al., 2015; Simpkins, Little, Weiss, 2004). Poor quality experiences, in contrast, can yield dissatisfaction, a belief that time in the activity was poorly spent, and disengagement (Beymer, Rosenberg, Schmidt, \& Naftzger, 2018; Ellis, Taggart, Martz, Lepley, \& Jamal, 2016).

Poor quality experiences also result in attrition. Attrition plagues 4- $\mathrm{H}$ and many other youthserving programs. Almost half of newly enrolled 4-H members drop out after only 1 year (Hamilton, Northern, \& Neff, 2014; Hartley, 1983). As Granger and Kane (2004) eloquently point out, "No program can make a difference if it does not change the daily experiences of young people, and it cannot do that if attendance is poor" (p. 52). Practitioners must design their programs to be engaging, immersive, and absorbing (Ellis, Freeman, Jamal, \& Jiang, 2017; Pine \& Gilmore, 2011) enough to increase the chances of a youth staying in a program long enough to make a difference, or thrive (Arnold, 2018; Hansen \& Larson, 2007; Strobel, Kirshner, O'Donoghue, \& McLaughlin, 2008).

Marketing research (Pine \& Gilmore, 2011) has identified four strategies commonly used by theme parks, restaurants, resorts, and other "experience industry" organizations to create engaging, immersive, and absorbing immediate visitor experiences. These strategies include using a pervasive theme that invites visitors to feel like they are part of a story, introducing multi-sensory elements to the activity or event, providing memorabilia, and personalizing interactions. Visitors to one of Disney's theme parks, for example, will find themselves in one of many fully themed environments ranging from an old west theme ("Frontierland") to a setting in the distant future ("Tomorrowland"). Sensory elements, such as the smell of popcorn and the sound of famous Disney songs are creatively introduced into the environment. Interactions with "cast members" and personnel dressed as Disney cartoon characters are individualized to the needs of visitors. Personalization of experiences is also a part of the Disney experience. Timid toddlers may cling to their mothers while characters strategically stand by their side for family photographs, while exuberant teenagers and young adults hug the characters with enthusiasm and passion. Memorabilia opportunities through photographs, souvenirs, and other mechanisms abound. Social science knowledge about the applicability of these strategies to youth programs is, however, limited. This field-based evaluation study thus examined the effect of these four strategies on quality of experience of youth participants in a special interest 4-H club (Ellis, Jiang, Lacanienta, \& Carroll, 2019; Lacanienta, Ellis, Taggart, Wilder, \& Carroll, 2018; Taggart, 2017). 


\section{Background}

\section{Quality of Immediate Experiences}

The quality of immediate experience has been a topic of interest among scholars in psychology and leisure studies for several decades. One of the first researchers to study immediate subjective experience was Abraham Maslow (1954/2014; 1971). Maslow asked 190 of his students to

Think of the most wonderful experience or experiences of your life; happiest moments, moments of rapture, perhaps from being in love or from listening to music or from suddenly 'being hit' by a book or a painting or from some great creative moment (p. 66). Based on these interviews, Maslow reported the experiential nature of immediate peak experiences:

A characteristic disorientation in time and space [occurs] . . In the creative furor, the poet or artist becomes oblivious to his surroundings, and of the passage of time. It is impossible for him when he wakes up to judge how much time has passed. Frequently he has to shake his head as if emerging from a daze to rediscover where he is. But more than this is the frequent report. .. of the complete loss of extension in time. Not only does time pass . . . with a frightening rapidity so that a day may pass as if it were a minute, but also a minute so intensely lived may feel like a day or a year ( $p .73)$.

In the decades following, social scientists have proposed frameworks for creating immediate experiences that present participants with opportunities to have deep, quality experiences (e.g., Ackerman, 1999; Csikszentmihalyi, 1975; Csikszentmihalyi \& Kleiber, 1991; Heath \& Heath, 2017). Perhaps the most impactful of these frameworks is Csikszentmihalyi's classic "flow" (1975) concept. People describe their flow experiences as being very similar to peak experiences. Time seems to speed up or slow down, their actions and reactions occur automatically, and concentration is fluidly and effortlessly focused clearly and exclusively on performing the activity at hand. Within a decade following publication of Csikszentmihalyi's first book on flow, the body of literature about that phenomenon was already referred to as classic (Mannell \& Iso-Ahola, 1987). The flow concept has been broadly applied to many arenas of public service, including education, business, health, tourism, and recreation services. 


\section{Quality of Experience}

The "theory of structured experience" ([TSE], Ellis, Freeman, Jamal, \& Jiang, 2017) is a recent development. TSE is founded on peak experience, flow, and related bodies of literature. TSE regards structured experiences as planned invitations extended by an experience provider for a flow-like "deep structured experience" to occur (Ellis, Freeman, Jamal, \& Jiang, 2017). Many youth meetings, events, activities, and competitions can be considered to be planned invitations for experiences. Within TSE, primary indicators of the quality of a structured experience include the prevalence of deep structured experience and the degree of engagement participants have during the activity. In TSE, experience quality is also reflected in post-hoc evaluations of participants' experiences (Cutler \& Carmichael, 2010). Quality experiences yield delight and a perception that the activity was a wise and valuable investment of time.

\section{Deep Structured Experience}

Deep structured experience is defined in TSE as "a state of effortless concentration during which individuals lose (a) their sense of time, (b) their thoughts about themselves, and (c) awareness of their problems. Participants will have "a genuine interest in the activity in which they are involved and a strong desire to continue doing that activity" (Ellis, Freeman, Jamal, \& Jiang, 2017, p. 12). When deep structured experience occurs in an activity requiring performance (such as playing a sport, creating a sculpture, singing a song, or acting in a play), it is fully equivalent to Csikszentmihalyi's (1975) "flow" phenomenon. The challenge of the activity must be commensurate with the skill level of the participant for flow or deep structured experience to occur. Unlike flow, deep structured experiences can occur during activities that do not require performance; a match between the challenge of the activity and the skill of the participant is not relevant. Examples of such activities are those in which participants direct their attention to unfolding stories (e.g., watching a sport event, attending a movie, engaging in conversation, learning from a teacher's lesson) and activities where the focus of attention is on sensory stimulation (e.g., enjoying a beautiful sunset or savoring a delicious desert).

Like flow, deep structured experience is a binary phenomenon (Ellis, Freeman, Jiang, \& Lacanienta, 2018). That is, people are "in" or "not in" deep structured experience at any given time during an activity (Ellis, Lacanienta, \& Freeman, 2018). Quality experiences are those during which participants report being in deep structured experience for a high percentage of time they participated in the activity. A 4-H participant in a shooting competition might, for example, report having been in deep structured experience for $60 \%$ of the competition. A high prevalence of deep structured experience is an element of the quality of an immediate experience (Ellis, Lacanienta, Freeman \& Hill, 2018). 


\section{Engagement}

Engagement is "the extent to which participants report active motivational involvement in a structured experience" (Ellis et al., 2016, p. 6). The formal TSE definition and questionnaire for measuring engagement is based on Reeve's (2012) position that immediate, situational engagement is comprised of four dimensions: interest, attention, motivation, and agentic inclinations. Agentic inclinations are the felt need for some form of proactive, intentional action. During a competition, an engaged youth might feel the need to try a certain strategy. While learning from a demonstration of livestock showing, an engaged youth will feel eager to actually practice the techniques being demonstrated.

\section{Delight}

Delight has been defined as "an extreme form of satisfaction" (Oliver, 2010). The concept has been of keen interest in tourism and hospitality management (Crotts \& Magnini, 2011; Crotts, Pan, \& Raschid, 2008; Magnini, Crotts, \& Zehrer, 2011; Torres \& Kline, 2013) The TSE operationalization of delight, though, follows from Oliver's definition. Delight is considered to vary along a continuum. "Delighted" and "disgusted" are the opposite ends of the continuum. Intermediate points on the continuum are "satisfied," "neither satisfied nor dissatisfied," "dissatisfied," and "disgusted."

\section{Meaningfulness}

Meaningfulness has been defined as "the extent to which the structured experience yielded active thought about something learned during that experience" (Ellis et al., 2016, p. 7). This TSE operationalization of meaningfulness has been used to evaluate an approach for classifying the effectiveness of 4-H meetings (Ellis et al., 2016). Meetings high in both engagement and perceived value of time spent are classified as "positive youth development" meetings. Meetings low in engagement, but high in perceived value of time spent are "instrumental meetings," and meetings high in engagement but low in perceived value of time spent are "hedonic" meetings. Meetings low on both variables are "unproductive meetings." Meaningfulness scores for "positive youth development" meetings were significantly higher than meetings classified as "hedonic," "instrumental," or "unproductive." 


\section{Perceived Value of Time Spent}

Perceived value of time spent refers to the individuals' degree of contentment with her or his decision to commit time and personal resources to participate in the structured experience (Ellis et al., 2016). Perceived value has been studied extensively in the business and tourism literature (e.g., Petrick, 2002; Zeithaml, 1988), but those constructions of perceived value focus on the financial value of specific product or activity features. In TSE perceived value is a measure of the extent to which participants are content with their investment of time and other unspecified resources in the activity. Quality experiences have occurred when participants report that their investments of time and resources were wise and that they are pleased they chose to participate in the activity.

\section{Strategies for Promoting Quality Experiences}

\section{Theming}

Theming refers to the use of props, cues, and communication that invites participants to use their imagination to transport themselves to another place, time, or set of circumstances (Ellis, Jiang, Lacanienta, \& Carroll, 2019). When an activity is well-themed, participants report feeling like they were "in a story" (Ellis, Jiang, Lacanienta, Carroll, \& Taggart, 2019). Theming "...is recognized as one of the most powerful tools that managers can utilize-the conception and implementation of an effective theme are the key factors in creating an irresistible customer impression" (Åstrøm 2017 p. 125). A hiking experience could be themed, for example, by contextualizing the hike as an imaginary quest by medieval period knights combing the countryside for villains threatening an assault on their village.

A recent study in the context of youth programs demonstrated the potentially powerful effect of theme (Ellis, Jiang, Lacanienta, \& Carroll, 2019; Lacanienta et al., 2018). Researchers conducted a field experiment by systematically theming and withholding theme from select activities during a 4-H youth camp. Themes were added to activities by using props and cues creating imaginary storylines. A climbing activity theme, for example, was presented as a storyline in which campers were challenged to climb a wall in order to escape a mob of marauding bandits. Themed experiences have been found to be exceptionally strong for participants who chose to co-create (Prahalad \& Ramaswamy, 2004) by engaging with the props, cues, and story line presented by the activity leader. 


\section{Quality of Experience}

\section{Engage Multiple Senses}

Sensory experiences beyond those inherent to the activity have also been shown to have a substantial impact on consumer experiences and purchasing behavior (e.g., Morrison, Gan, Dubelaar, \& Oppewal, 2011; Warrenburg, 2005). Some retail stores, for example, add pleasant aromas to enhance shoppers' experiences. A sensory element might be added to a kayaking experience by asking participants to stop paddling and listen to the nature sounds around them, the splash of jumping fish, the songs of nearby birds, and the rustle of wind in nearby trees. Kayakers might be asked to place their hands under the surface of the water and contrast the cool water with the hot summer air around them.

\section{Memorabilia}

The effects of memorabilia have been consistently noted in the literature on tourism (e.g., Swanson, 2004; Wong \& Cheng, 2012) and quality management (e.g., Kano, 1984; Matzler, Hinterhuber, Bailom, \& Sauerwein, 1996). Examples are souvenirs, photographs, and unanticipated gifts. Personalization, or "one-to-one marketing," elevates consumer experiences and affects purchase behaviors (e.g., Vesanen, 2007; Arora, et al., 2008).

\section{Personalization}

Pine and Gilmore (2011) stress that top organizations in the business of providing experiences for people customize their offerings to the level of the individual customer, not simply to meeting the needs of the market to which a given customer belongs. In more general terms, this principle means that every participant has unique interests, needs, wants, and histories. Personalization is the process through which astute youth leaders capitalize on that uniqueness. Experiences may be personalized in a number of ways during the course of a structured experience. A youth leader welcoming a participant to a structured kayaking experience might, for example, share her or his admiration for an article of clothing a participant wears (e.g., "What a fine kayaking hat you have!"), a piece of equipment the participant brings to the event ("I have a paddle just like the one you brought, and I love it!"), or something the participant does during the activity ("You are a very bold person to try this activity even though you said you are afraid of water!"). 


\section{Hypotheses}

Despite the popularity of theme, multi-sensory appeal, memorabilia, and personalization in many sectors of the experience industries, the efficacy of these techniques in youth services has not been thoroughly investigated. Youth programs are a unique context; they tend to be very rich in complexity. Many features compete for participants' attention. Friends with similar interests are almost always at participants' sides providing rich opportunity for playfulness as well as constructive and casual conversation. Adult leaders are also present to interact and have rapport with youth participants (Sibthorp, Paisley \& Gookin, 2007). An agenda or set of expectations for action during the structured experience is present. The anticipated action is ordinarily interesting and self-relevant to youth participants (Akiva, Carey, Cross, DelaleO'Connor, \& Brown, 2017). Some participants may be apprehensive about their ability to execute a performance or complete a task that will be part of a structured experience during a meeting, competition, or event. In brief, many elements of the experience compete for a youth participants' attention. Attempts to introduce themes, multisensory appeals, personalization, and memorabilia may become only a small and largely unnoticed part of the broader experience. In brief, theme, multi-sensory appeal, personalization, and memorabilia are strategies commonly used in business and the commercial recreation and tourism industry to create quality experiences for customers, visitors, and guests. But, can they be effective in the context of youth meetings, events, and programs? This study tested the following hypotheses:

1. $\mathrm{H}_{1}$ : Themed activities increase the quality of structured experiences of youth.

2. $\mathrm{H}_{2}$ : Multi-sensory elements increase the quality of structured experiences of youth

3. $\mathrm{H}_{3}$ : Personalization increases the quality of structured experiences of youth

4. $\mathrm{H}_{4}$ : Memorabilia increases the quality of structured experiences of youth

\section{Method}

\section{Setting}

We, the researchers, created a 4-H special interest (SPIN) club to study the effects of the four strategies. 4-H special interest clubs have different names in different states, but they share common features. They are short-term programs, typically six to eight weeks long through which 4-H members learn and experience specialized topics. SPIN clubs address needs of families who are accustomed to seasonal youth activities, e.g., soccer in spring, baseball in summer, football in fall. Although SPIN clubs may address any of a wide range of topics, the 
common goal is to advance the fundamental mission of 4-H: pledging the "head to clear thinking, heart to greater loyalty, hands to larger service, health to better living."

Club members participated in eight consecutive weekly meetings, each held on a Saturday at 9 a.m. for 3 hours. The activities included high ropes course initiatives, orienteering, outdoor cooking, rock climbing, plant and insect identification, archery, canoeing, map and compass, kayaking, and a service project. Not all meetings, of course, lasted exactly three hours. Some activities finished a few minutes early, and occasionally parents were late in arriving to take their sons or daughters home. Little variation, however, existed in the "dosage" from session to session. Each meeting was facilitated by a guest instructor each week, with the researchers introducing the guest instructor to the youth participants at the beginning of each meeting.

\section{Participants}

Thirty youth between the ages of 8 and 17 participated in the club. Participants were recruited through existing 4-H clubs, word of mouth promotion, and social media. Both girls (53\%) and boys (47\%) participated.

\section{Measurement}

\section{Deep Structured Experience}

Consistent with previous research (Ellis, Freeman, et al., 2018; Stricklin \& Ellis, 2018), deep structured experience was measured using a graphic approach. Participants were presented with the definition of deep structured experience, followed by a rectangle extending from one side of the paper questionnaire to the opposite side. The left side of the rectangle represented the beginning of the activity and the right side represented the end of the activity. Participants were asked to draw lines between the two ends to represent the occasions that they were "in" deep structured experience. The sum of the length of all lines drawn divided by the length of the rectangle served as a measure of prevalence of deep structured experience. Correlations between deep structured experience prevalence and other indicators of quality of immediate experience (engagement, immersion, absorption, delight) ranging from .45 to .72 have been reported (Ellis, Freeman, Jiang, \& Lacanienta, 2018). 


\section{Engagement}

The TSE engagement scale includes four items, each following the stem, "During this meeting ..." An example item is, "I felt excited about things we were doing." Participants placed a mark on a line between two anchor points to represent their status relative to each item. The anchor points were "none of the time" and "all of the time." Scores were calculated by measuring the distance between the participant's mark and the "none of the time" response. That distance was divided by the total length of the line, giving an estimate of the percentage of time during the meeting that the participant felt engaged (Lacanienta et al., 2018). Reliability and validity evidence has been reported in other studies (Ellis et al., 2016; Lacanienta et al., 2018; Ellis, Jiang, Lacanienta, \& Carroll, 2019).

\section{Perceived Value of Time Spent}

Five items are included on the TSE questionnaire measuring perceived value of time spent (Ellis et al., 2016). Examples are "doing this activity was an excellent use of my time" and "I chose wisely when I chose to do this activity." Significant correlations have been found between perceived value of time spent and the following variables: customer service quality (Stricklin \& Ellis, 2018), provider vs. participant structured experiences (Ellis, Freeman, \& Jiang, 2017), feelings of safety and support (Ellis et al., 2016), and deep structured experience (Ellis, Freeman, Jiang, \& Lacanienta, 2018). The alpha reliability coefficient from the study reported here was .93.

\section{Meaningfulness}

A single item measure was used to measure meaningfulness: "I am still thinking about something that happened" (Ellis et al., 2016). Meaningfulness scores discriminated significantly among meetings categorized as being either positive youth development, instrumental, hedonic, or unproductive. The meaningfulness mean for positive youth development scores was 4.05 , as compared to 3.3 for the unproductive meeting.

\section{Delight}

Delight is an extreme form of satisfaction (Oliver, 2010; Schneider \& Bowen, 1999; Torres \& Kline, 2006; Torres \& Kline, 2013). A single-item asked participants "How did you like the meeting?" Response options range from 1 (the worst) to 5 (awesome). This operationalization is different from approaches used by previous researchers who have studied delight. Typically, 


\section{Quality of Experience}

a single item is used, with "delight" at the high end of the scale and "failure," "disgust," or a similar adjective at the opposite end of the scale (Spitzer, 2007; Lee, Ralston, Ellis, \& Park, 2011; Oliver, 2010). We chose to use "the worst" and "awesome" because, in our experience in working with youth, those descriptors are used in day-to-day conversation. Our delight measure departs from the TSE approach and might be better characterized as a single-item index than a single-item scale (Diamantopoulos \& Winklhofer, 2001).

\section{Procedure}

An informational meeting was held during the first week of the program. Subsequent SPIN club sessions proceeded according to the agenda presented in Table 1. As shown in Table 1, each meeting was conducted according to a unique combination of the four structuring strategies: theme, multi-sensory appeal, memorabilia, and personalization. Formal definitions of each of the four strategies are presented in Table 2. The treatment condition combinations are based on an "orthogonal array." Using an orthogonal array mathematically eliminates ambiguity with respect to attribution of an observed cause and effect relation. All factors in an orthogonal array are uncorrelated. An effect we might observe for theme, for example, is not confounded by the presence of any of the other structuring strategies. Each profile of structuring strategies was randomly assigned to one of the eight meetings.

Table 1. Meeting Logistics and Protocol

\begin{tabular}{|c|c|c|c|c|c|c|}
\hline Meeting & Activity & Location & $\begin{array}{l}\stackrel{\mathscr{E}}{E} \\
\stackrel{\boldsymbol{E}}{\boldsymbol{F}}\end{array}$ & 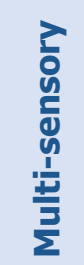 & 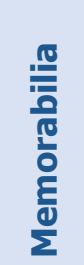 & 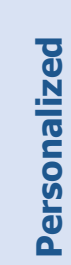 \\
\hline 1 & Challenge course (low ropes) & Ropes course & Yes & No & Yes & No \\
\hline 2 & Outdoor cooking & County 4-H office & Yes & No & No & Yes \\
\hline 3 & Indoor rock climbing & Campus rec. center & Yes & Yes & No & No \\
\hline 4 & Map and compass & Nature reserve & Yes & Yes & Yes & Yes \\
\hline 5 & Plant and insect identification & Nature park & No & Yes & Yes & No \\
\hline 6 & Archery & Archery club & No & No & No & No \\
\hline 7 & Canoeing and kayaking & Nature reserve & No & Yes & No & Yes \\
\hline 8 & Service project: Local park clean-up & City park & No & No & Yes & Yes \\
\hline
\end{tabular}


Quality of Experience

Table 2. Definitions and Manipulation of Independent Variables

\begin{tabular}{|c|c|c|c|}
\hline Factor & Definition & $\begin{array}{l}\text { Activity sessions } \\
\text { implemented }\end{array}$ & $\begin{array}{l}\text { Example of } \\
\text { implementation }\end{array}$ \\
\hline Theme & $\begin{array}{l}\text { A strategy in which a set of } \\
\text { visual, auditory, tactile, } \\
\text { olfactory, and taste cues } \\
\text { are used to communicate } \\
\text { an imaginary setting, story, } \\
\text { or set of circumstances and } \\
\text { a story line regarding those } \\
\text { circumstances. }\end{array}$ & $\begin{array}{l}\text { Ropes course, outdoor } \\
\text { cooking, rock climbing, } \\
\text { map and compass }\end{array}$ & $\begin{array}{l}\text { The ropes course theme } \\
\text { was "pirates." The youth } \\
\text { dressed up as pirates and } \\
\text { took on pirate names that } \\
\text { the instructors referred to } \\
\text { the entire time. All } \\
\text { activities were nautically- } \\
\text { and pirate-themed. }\end{array}$ \\
\hline $\begin{array}{l}\text { Multi-sensory } \\
\text { elements }\end{array}$ & $\begin{array}{l}\text { A strategy in which sensory } \\
\text { cues that are not inherent } \\
\text { to the essential behavioral } \\
\text { elements of an activity are } \\
\text { introduced to the activity } \\
\text { context and brought to the } \\
\text { attention of the participant. }\end{array}$ & $\begin{array}{l}\text { Map and compass, } \\
\text { plant and insect } \\
\text { identification, } \\
\text { canoeing and kayaking }\end{array}$ & $\begin{array}{l}\text { The canoeing and kayak } \\
\text { experience included } \\
\text { pausing to listen to sounds } \\
\text { in the natural environment } \\
\text { and touching the water to } \\
\text { experience its } \\
\text { temperature. }\end{array}$ \\
\hline Memorabilia & $\begin{array}{l}\text { A tangible object } \\
\text { unexpectedly presented to } \\
\text { a participant as a gift at or } \\
\text { near the conclusion of } \\
\text { behavioral engagement in } \\
\text { the experience. }\end{array}$ & $\begin{array}{l}\text { Ropes course, map } \\
\text { and compass, plant } \\
\text { and insect } \\
\text { identification, service } \\
\text { project }\end{array}$ & $\begin{array}{l}\text { At the end of the map and } \\
\text { compass activity, all } \\
\text { participants were given a } \\
\text { carabineer and compass to } \\
\text { keep. }\end{array}$ \\
\hline Personalization & $\begin{array}{l}\text { A strategy in which visual or } \\
\text { verbal cues are provided to } \\
\text { highlight the identity and/or } \\
\text { other unique characteristics } \\
\text { of a participant. }\end{array}$ & $\begin{array}{l}\text { Outdoor cooking, map } \\
\text { and compass, } \\
\text { canoeing and } \\
\text { kayaking, service } \\
\text { project }\end{array}$ & $\begin{array}{l}\text { During the outdoor } \\
\text { cooking experience each } \\
\text { youth received a chef hat } \\
\text { with their name on it, } \\
\text { which they all wore } \\
\text { throughout the activity. }\end{array}$ \\
\hline
\end{tabular}

Complete control over the quality of implementation of the theme was not possible because guest instructors external to the research project led club members through each of the activities. These individuals were informed of the theme of their respective activity, and the researchers discussed implementation of the theme with the instructors. As the study 


\section{Quality of Experience}

progressed, however, it was very evident that some instructors were much more adept and committed than others to implementing their assigned themes. Substantial variation was evident in the quality of implementation across the four activity sessions that were themed.

\section{Table 3. Evaluated Levels of Theme}

\begin{tabular}{|c|c|c|}
\hline Level & $\begin{array}{l}\text { Geometric } \\
\text { mean }\end{array}$ & Rubric \\
\hline $\begin{array}{l}\text { Level 5: Absolutely } \\
\text { perfect }\end{array}$ & 332 & $\begin{array}{l}\text { An improvisational story is enacted throughout the entire activity. } \\
\text { Themed props and decorations evoke a sense of being in a } \\
\text { different place and time. Participant interactions indicate that all } \\
\text { participants are keenly invested in the theme. }\end{array}$ \\
\hline Level 4: Very good & 141 & $\begin{array}{l}\text { An improvisational story is enacted throughout most of the } \\
\text { activity. Themed props and decorations evoke a sense of being in } \\
\text { a different place and time. Most participants show investment } \\
\text { and interest in the theme, but a small number of participants may } \\
\text { choose to disengage from the theme. }\end{array}$ \\
\hline Level 3: Good & 107 & $\begin{array}{l}\text { An improvisational story is enacted during select parts of the } \\
\text { activity. Few themed props or decorations are present. Some } \\
\text { participants engage with the theme while others clearly do not } \\
\text { engage with the theme. }\end{array}$ \\
\hline Level 2: No theme & -- & $\begin{array}{l}\text { No presence of a story, themed props or decorations, or } \\
\text { reference to a different place and time. }\end{array}$ \\
\hline Level 1: Terrible & 6 & $\begin{array}{l}\text { Little attempt is made to implement a theme. Leaders and } \\
\text { participants are clearly not invested in a story. The story is rarely } \\
\text { or never referenced as the activity unfolds. If it is mentioned, the } \\
\text { comment may be made in jest. No themed props or decorations } \\
\text { are provided. }\end{array}$ \\
\hline
\end{tabular}

To compensate for this uneven quality, we developed and applied a rubric for evaluating the quality of implementation of the theme for the relevant club meetings (Table 3). The basis for the rubric is Lodge's (1981) research on magnitude scaling. Magnitude scaling uses psychophysics to calibrate unobservable constructs (attitudes, intentions, opinions) using tangible phenomena. In Lodge's studies of political attitudes, participants showed the strength of their approval or disapproval of political candidates by varying the intensity of lights, changing sound decibel levels to match the strength of their opinion, drawing lines of different 


\section{Quality of Experience}

length, and squeezing a hand grip device. Lodge also calibrated a set of adjectives varying in intensity by using these measures. Psychophysics assumes that relations between stimuli and people's subjective experience of those stimuli (e.g., How bright does the light seem to be? How loud does the sound seem to be?) are non-linear. Due to the non-linear relations, numeric judgements of intensity research participants provide are converted to common (base 10) logarithms. Geometric means are calculated to produce subjective intensity scores calibrated to the "real" intensities (e.g., light intensities, sound decibels). Using those procedures, Lodge derived intensity scores for 30 adjectives indicating differing levels of quality. "Absolutely perfect" quality, for example, was scaled at 332, "First rate" quality was 200, "so-so" quality was the reference phrase (scored 50), "unsatisfactory" quality was calibrated to a score of 12 , and "atrocious" quality was calibrated to a score of 4 . The scores in Table 3 are an application of Lodge's calibration to our evaluation of the quality of implementation of theme.

\section{Method of Data Analysis}

Data were analyzed in four phases. First, distributions of the outcome variables were examined through descriptive statistics and inspection of visual displays of the data. Means, standard deviations, skewness, and kurtosis were calculated. Histograms were used to visually examine the distributions of each of the five outcome variables. Weekly attendance records were plotted against attendance at five benchmark 4-H clubs provided by the local 4- $\mathrm{H}$ administration.

Next, principal components analysis was used to create a composite measure of quality of experience. The resulting component is thus derived from the matrix of correlations among deep structured experience prevalence, perceived value, delight, and engagement. Development of this composite score was appropriate due to the error rate that would result from analyzing each outcome variable separately. Testing hypotheses for each of the five outcome variables separately would have increased the experiment error rate from the conventional, $p=.23$ (for five comparisons) to $p=.64$ (for 20 comparisons, i.e., 1-[1-a] ${ }^{20}$; Maxwell, Delaney, \& Kelly, 2018). A unitary solution fit the data. Three of the five variables had loadings greater than .80 and the loadings of the remaining two variables exceeded .50 . The composite reliability (Raykov, 1997) of this congeneric measure of experience quality was .86 .

The third phase of data analysis was hypothesis testing. The effects of theme quality, multisensory appeal, personalization, and memorabilia on quality of experience (i.e., the composite measure from the principal components analysis) was tested using linear mixed modeling procedures. Mixed modeling was required to address the problem of lack of 


\section{Quality of Experience}

independence among observations. Lack of independence of observations resulted from the repeated measures of experiences of the same 30 participants across the eight meetings. The hypothesis tests were conducted at the $p<.05$ confidence level.

The fourth phase of data analysis involved comparing SPIN club attendance rates with attendance in benchmark clubs. A fundamental assumption of the SPIN club was that experience quality of the sessions would collectively elevate attendance. Thus, weekly attendance records were plotted and compared with the average of six benchmark clubs, selected with the assistance of the state $4-\mathrm{H}$ office. The benchmark clubs were considered to be reasonable for comparison by 4-H administration in terms of the age and sex of participants, their anticipated interest level, and time of the year of the club meetings.

\section{Results}

\section{Distributions of the Measures of Quality of Experience}

Descriptive statistics for the five measures of quality of experience are reported in Table 4 and the means per activity session are plotted in Figure 1. Means fell toward the upper end of their possible range for all of the measures of quality. Distributions showed negative skewness and three of the five measures were leptokurtic (more peaked than the normal curve). In other words, large frequencies of scores were clustered toward the upper range of possible scores. The distribution of the composite measure of experience quality (i.e., the principal component) also had notable negative skewness (-1.66) and positive kurtosis (leptokurtic, 3.11).

Figure 1 is a plot of quality of experience means (the principal component) per session. Three of the four sessions producing the highest quality of experience scores were themed sessions (climbing, outdoor cooking, and challenge course). The canoeing and kayaking session also produced a high score; that session was personalized and used multisensory strategies. Sessions producing the lowest scores on the quality of experience measure were the archery session and the map and compass section. The archery session used none of the four strategies, and the map and compass session used all of the strategies, but effectiveness of theming of that session was rated "terrible" by the observers. 
Table 4. Descriptive Statistics

\begin{tabular}{|c|c|c|c|c|c|c|c|c|}
\hline & $\boldsymbol{N}$ & Min & Max & Mean & $\begin{array}{l}\text { Standard } \\
\text { deviation }\end{array}$ & Skewness & Kurtosis & $\begin{array}{l}\text { PCA } \\
\text { loading }\end{array}$ \\
\hline $\begin{array}{l}\text { Deep structured } \\
\text { experience prevalence }\end{array}$ & 154 & .00 & 1.00 & .80 & .27 & -1.50 & 1.32 & .58 \\
\hline Delight & 156 & 1.00 & 5.00 & 4.37 & .89 & -1.61 & 2.47 & .85 \\
\hline Perceived value & 161 & 1.00 & 5.00 & 4.43 & .84 & -1.84 & 3.37 & .86 \\
\hline Meaningfulness & 160 & 1.00 & 5.00 & 3.67 & 1.24 & -.76 & -.34 & .52 \\
\hline Engagement & 160 & .01 & 1.00 & .66 & .24 & -.57 & -.24 & .83 \\
\hline $\begin{array}{l}\text { Experience quality } \\
\text { (Principal Component) }\end{array}$ & 148 & -3.70 & 1.04 & 0 & .94 & -1.66 & 3.11 & -- \\
\hline
\end{tabular}

Note. PCA = Principal Components Analysis. One component explained $55.18 \%$ of the variance among the five measures. Composite reliability was .86 .

Figure 1. Experience Quality Means (Principal Component) per Session

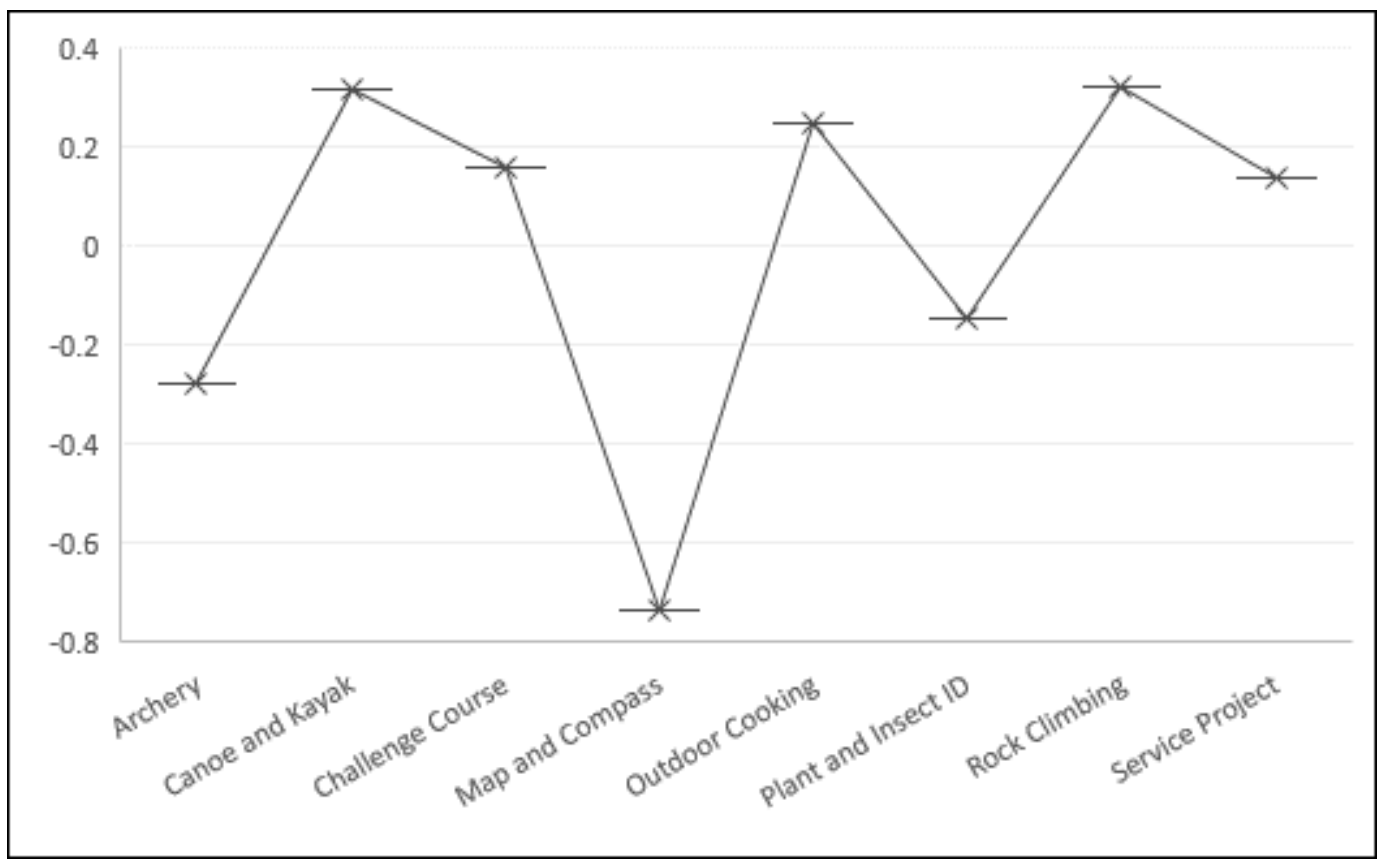




\section{Hypothesis Tests}

Two of the experience structuring strategies had a significant effect on quality of experience: execution of theme $\left(F_{4,117}=5.75, p<.01, R_{p}^{2}=.11\right)$ and personalization $\left(F_{4,117}=5.73, p<.05\right.$, $\left.R_{p}^{2}=.02\right)$. The effect of multi-sensory appeal $\left(F_{4,117}=.32, p>.05, R_{p}^{2} \leq .01\right)$ and memorabilia $\left(F_{4,117}=.62, p>.05, R_{p}^{2} \leq .01\right)$ were not significant.

The two sets of experience quality means corresponding to the two strategies found to be significant (theme and personalization) are plotted in Figure 2. Four sessions were themed. The three sessions in which the theme implementation was rated "good," "very good," or "absolutely perfect produced higher quality of experience ( $\bar{X}=.34, n=3$ sessions) than the no theme ( $\bar{X}=.00, n=4$ sessions) and the session rated "terrible attempt" to implement theme ( $\bar{X}=-1.02 ; n=1$ session). The four personalized sessions produced a significantly higher quality of experience than the four not personalized sessions $\left(\bar{X}_{\text {personalized }}=.22\right.$ vs. $\bar{X}_{\text {not_personalized }}=$ $-.22)$.

Figure 2. Experience Quality Means (Principal Component) for Effectiveness of Theme Implementation and Personalization

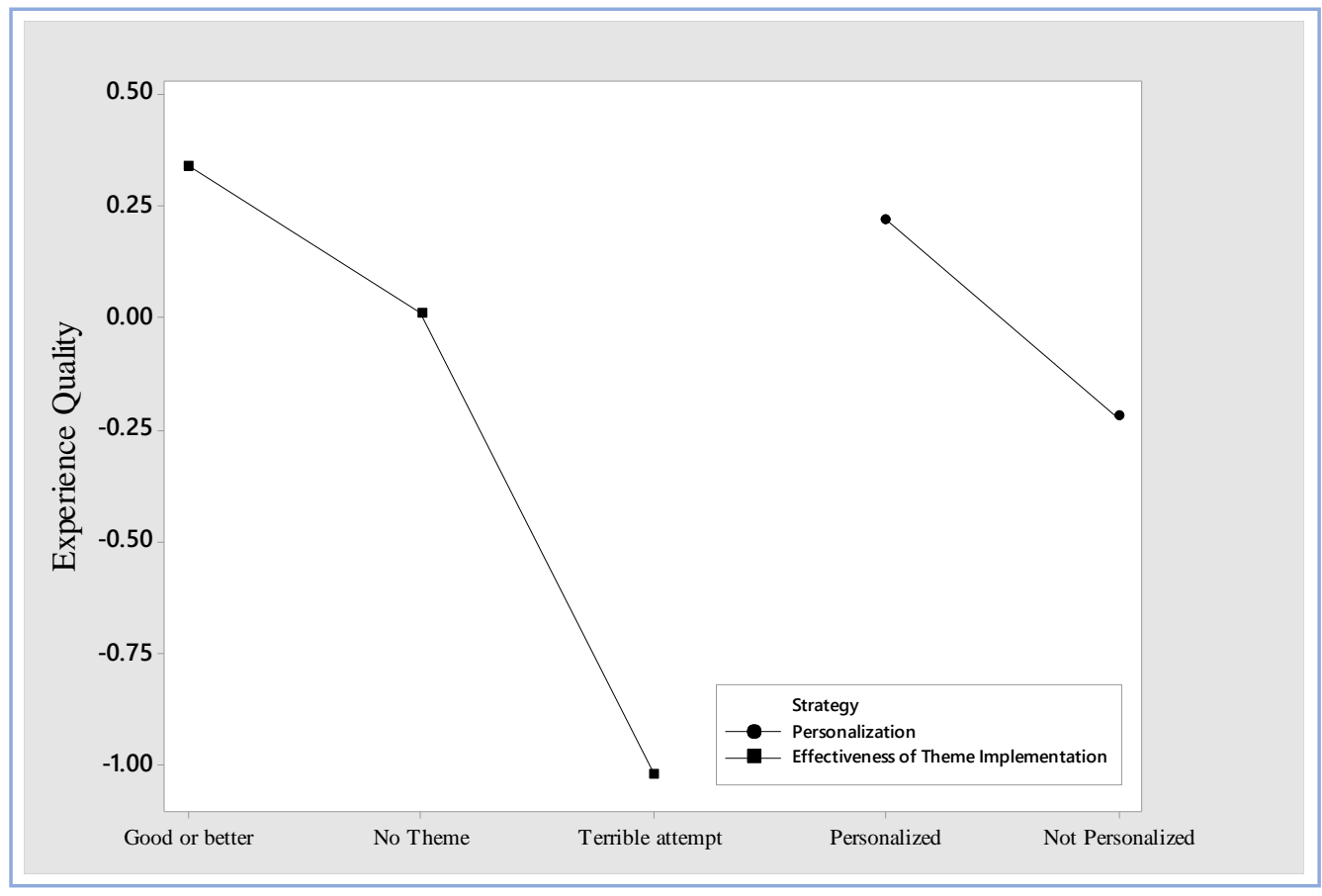




\section{Attendance}

Figure 3 provides the plot of SPIN club attendance and the average attendance of the six benchmark clubs. SPIN club attendance was higher than the benchmark average for all sessions.

Figure 3. Attendance Data of 4-H Outdoor Adventure SPIN Club

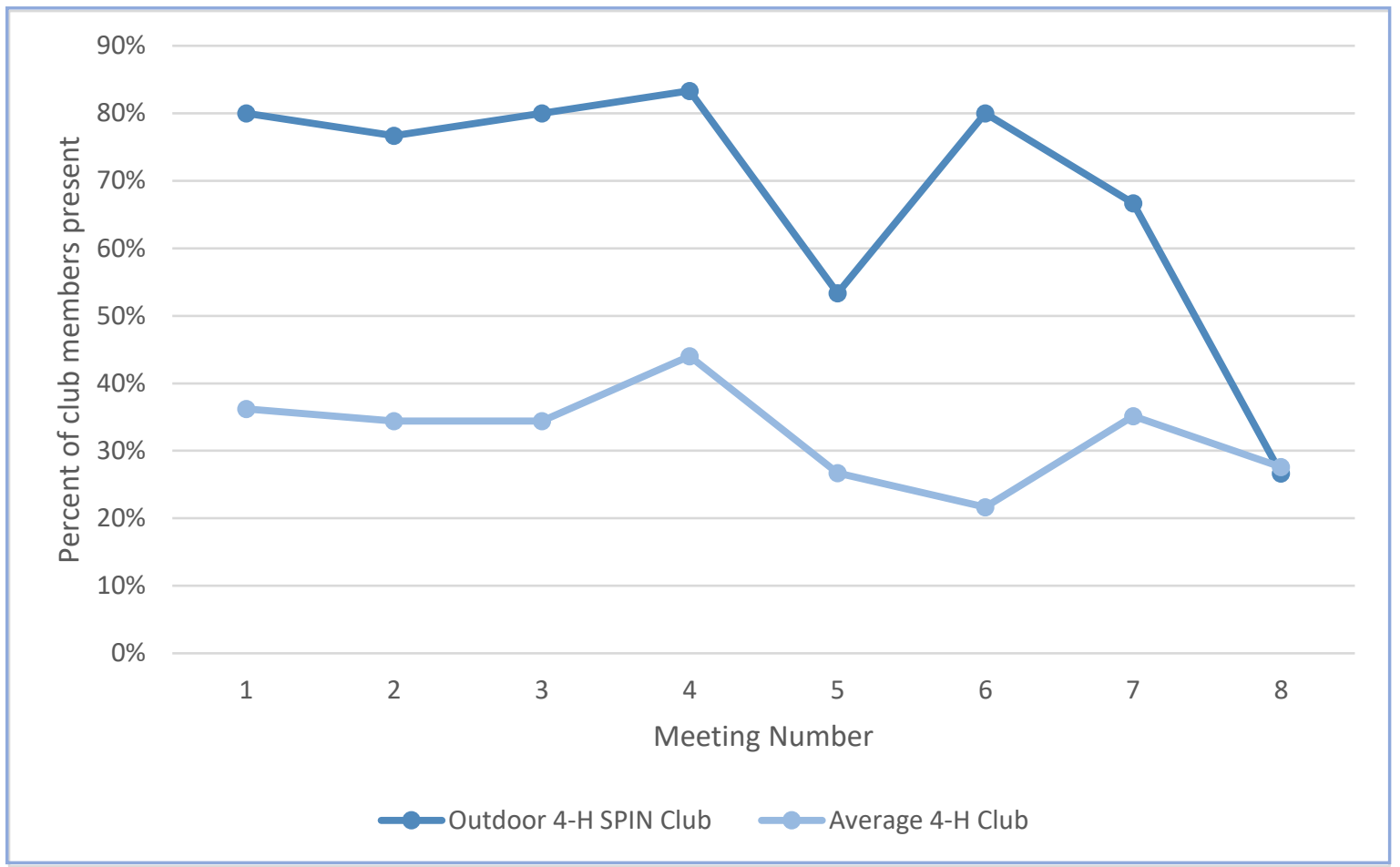

For five of the eight sessions, attendance exceeded $80 \%$. These results are, of course, correlational and not experimental, so confidence in a cause-and-effect relation between using the four strategies (i.e., theme, personalization, multi-sensory appeal, and memorabilia), experience quality, and attendance is limited. Numerous features of clubs impact attendance. Nonetheless, the data in Figure 3 are consistent with the assumption that use of the strategies tends to increase attendance.

\section{Summary and Implications}

We examined the effect of four point-of-service features (i.e. efficacy of theme implementation, multi-sensory appeal, personalization, and memorabilia) on the quality of experience of youth in 


\section{Quality of Experience}

structured program experiences. Effectiveness of implementation of theme and personalization of experiences were found to have a significant effect on quality of experiences. Weekly attendance for the SPIN club was substantially higher than benchmark clubs. Results are consistent with Pine and Gilmore's (2011) observations about the effect of theme and personalization of experiences and with the authors' own research on theming (Ellis, Jiang, Lacanienta, \& Carroll, 2019). School events, fairs, roundups, scout troop meetings, club gatherings, and even sporting events are regularly themed to bring meaning and value to participants. It is evident from the results of this study that theme also brought meaning and value to this 4-H club. The value of personalization of experiences is also affirmed by the data. Themes yield delight, deep experience, perceptions of time being valued, and meaningfulness.

Effects of the memorabilia and multisensory appeal strategies were not significant. But, it is important to note that implementation of these strategies was far from optimal, as a result of the field-based design. We sometimes distributed memorabilia during awkward periods of transition, as meetings ended and youth were scrambling to gather belongings or leave with parents. As a result, many participants did not seem to take notice of the gifts they received. We did not successfully integrate the multisensory elements into the structure of the experience in all of the activities. Instead, multisensory experiences sometimes were brief occasions on which participants gathered for the purpose of sensory experience instead of being "woven into the fabric" of the overall activity. During canoeing and kayaking, for example, youth paddled boats to the middle of a small lake, where they were invited to listen to the sounds of nature, touch the surface of the water to feel its coolness, and notice the contrasts of colors and shapes of clouds in the sky. Then, they resumed their non-themed, personalized paddling experience. This multisensory element consumed approximately 10-minutes of the 90-minute session (11\%). During other activities, multisensory elements were much better integrated. For the indoor climbing wall structured experience, for example, sounds of birds chirping were added through hidden speakers and nature scents were added by hiding cotton balls saturated with scents at different locations on the climbing wall.

These methodological issues illustrate a general challenge in conducting field research on structured experiences for youth. While elements of any given strategy may be implemented, other elements will vary by activity. Execution of a theme, for example, will involve specific props and cues suggesting a different time, place, or set of circumstances, but the story line associated with the theme will necessarily vary according to the nature of the activity. A story line for a climbing experience on a challenge course might, for example, involve evading a pursuing enemy, while the story line for fishing might involve a group of bold young 


\section{Quality of Experience}

adventurers trying to catch a monster catfish that has been threatening to begin feasting on people.

It is not possible to fully standardize experimental treatments in field studies of these strategies. As such, studies such as the one described in this paper might be better characterized as evaluation research instead of field experiments. Despite these limitations, results of the evaluation and consideration of the previous research on which the evaluation is based provide warrant for the following suggestions to leaders of structured experiences for youth:

1. Consider theming the structured experience. Use props, cues, and a story line to invite participants to an imaginary place, time, and set of circumstances. Ensure that the theme is pervasive throughout the structured experience by working with practitioners, staff, volunteers, or other youth leaders. Try to not let interactions drift in and out of the imaginary story line.

2. Personalize your encounters with participants. Find ways they are unique and celebrate those.

3. Consider building into your program evaluation strategies questionnaires measuring the quality of immediate subjective experiences, such as deep structured experience and engagement. Such measures can provide very helpful information in addition to the traditional post-hoc satisfaction measures.

4. Field researchers who use a similar design should build stronger manipulation checks into their studies. Manipulation checks would ensure that participants actually noticed the themes, multisensory elements, memorabilia, personalization, or other strategies used to elevate the quality of the experience of participants.

5. Applied researchers interested in advancing knowledge about strategies for structuring experiences might consider laboratory approaches. Such approaches will substantially increase the fidelity of treatment implementation (construct validity of causes) and will substantially reduce the effects of random and extraneous factors, such as weather conditions, co-participants' behavior, and activity specialist skill. A creative researcher may be able to establish highly controlled conditions in a field setting. A brief structured experience might be conducted during a field-based experience.

\section{References}

Ackerman, D. (1999). Deep Play. New York: Vintage Books. 
Quality of Experience

Akiva, T., Carey, R. L., Cross, A. B., Delale-O'Connor, L., \& Brown, M. R. (2017) Reasons youth engage in activism programs: Social justice or sanctuary?. Journal of Applied Developmental Psychology, 53, 20-30. doi:10.1016। J.appdev.2017.08.005

Arora, N., Dreze, X., Ghose, A., Hess, J. D., Iyengar, R., Jing, B., . . Zhang, J. (2008). Putting one-toone marketing to work: Personalization, customization, and choice. Marketing Letters, 19(3-4), 305. doi:10.1007/s11002-008-9056-z

Arnold, M. (2018) From context to outcomes: A thriving model for 4-H youth development programs. Journal of Human Sciences and Extension, 6(1), 141-160.

Åstrøm, J. K. (2017) "Theme factors that drive the tourist customer experience", International Journal of Culture, Tourism and Hospitality Research, 11 (2), 125-141. doi:10.1108/IJCTHR-07-2015-0070

Beymer, P., Rosenberg, J., Schmidt, J., \& Naftzger, N. (2018). Examining relationships among choice, affect, and engagement in summer STEM programs. Journal of Youth and Adolescence, 47, 1178-1197. doi:10.1007/s10964-018-0814-9

Bowers, E. P., Geldhof, G. J., Johnson, S. K., Hilliard, L. J., Hershberg, R. M., Lerner, J. V., \& Lerner, R. M. (2015). Promoting Positive Youth Development: Lessons from the 4-H study. Switzerland: Springer International.

Crotts, J. C., \& Magnini, V. P. (2011). The customer delight construct: is surprise essential? Annals of Tourism Research, 38(2), 719-722.

Crotts, J., Pan, B., \& Raschid, A. (2008). A survey method for identifying key drivers of guest delight. International Journal of Contemporary Hospitality Management, 20(4), 462-470. doi:10.1108/09596110810873552

Csikszentmihalyi, M. (1975). Beyond boredom and anxiety. San Francisco: Jossey-Bass.

Csikszentmihalyi, M. \& Kleiber, D. (1991). Leisure and self-actualization. In B. Driver, P. Brown, \& G. Peterson (Eds.) Benefits of leisure (pp. 91-102). State College, PA: Venture Publishing.

Cutler, S. \& Carmichael, B. (2010). The dimensions of the tourist experience. In M. Morgan, P. Lugosi, \& J. Ritchie (Eds.). The Tourism Experience (p. 3-26). Bristol: Channel View Publications.

Diamantopoulos, A., \& Winklhofer, H. M. (2001). Index construction with formative indicators: An alternative to scale development. Journal of Marketing Research, 38(2), 269-277. doi:10.1509/jmkr.38.2.269.18845

Ellis, G. D., Freeman, P., Jamal, T. \& Jiang, J. (2017). A theory of structured experience. Annals of Leisure Research, 22(1), 97-118. doi:10.1080/11745398.2017.1312468

Ellis, G. D., Freeman, P., \& Jiang, J. (2017) Creating Experiences for Study-Abroad Tourists. Journal of Tourism Insights, 8(1), 4. doi:10.9707/2328-0824.1072

Ellis, G. D., Freeman, P., Jiang, J. \& Lacanienta, A. (2018). Measurement of deep structured experience as a binary phenomenon. Annals of Leisure Research. doi:10.1080/11745398.2018.1429285 
Quality of Experience

Ellis, G. D., Lacanienta, A., \& Freeman, P. (2018). Reducing attrition from youth programs through structuring deep, valued, and impactful programs for youth. In P. Witt and L. Caldwell (eds.). Youth development principles and practices in out-of-school time settings. (pp. 351-387). Urbana, IL: Sagamore-Venture.

Ellis, G. D., Lacanienta, A., Freeman, P., \& Hill, B. (2018, June). Testing the presumed effects of service performance, theme, personalization, and multisensory appeal on quality of structured experiences. Paper presented at TTRA 2018 International Conference, Miami/Coral Gables, FL. https://scholarworks.umass.edu/ttra/2018/Academic_Papers_Oral/3/

Ellis, G., Jiang, J., Lacanienta, A., \& Carroll, M. (2019). Theme, co-creation, and quality of structured experiences at camp. Journal of Youth Development. 14 (1), 230-242. doi:10.5195/jyd.2019.651

Ellis, G. D., Jiang, J., Lacanienta, A., Carroll, M., \& Taggart, A. S. (2019). "'I felt like I was in a story': Effect of theme, lived experience of theme, and activity on quality of structured experiences of 4H campers". Paper presented at 2019 American Camp Association National Conference, Nashville, TN.

Ellis, G. D., Taggart, A. S., Martz, J., Lepley, T., \& Jamal, T. (2016). Monitoring Structured Experiences during Youth Programs: Development of Brief Measures of Perceived Value and Engagement. Journal Of Youth Development, 11(3), 159-174. doi:10.5195/jyd.2016.469

Granger, R. C., \& Kane, T. (2004, February 18). Improving the Quality of After-School Programs. Education Week, 23(23), pp. 52,76. Retrieved from http://www.edweek.org/ew/articles/2004/02/18/23granger.h23.html?qs=improving+the+quality +of+after-school+programs++inmeta:Cover_year\%3D2004\&print=1

Hamilton, S. F., Northern, A., \& Neff, R. (2014). Strengthening 4-H by Analyzing Enrollment Data. Journal of Extension.

Hansen, D. M., Larson, R. W. (2007). Amplifiers of developmental and negative experiences in organized activities: Dosage, motivation, lead roles, and adult-youth ratios. Journal of Applied Developmental Psychology. 28, 360-374. doi:10.1016/j.appdev.2007.04.006

Hartley, R. S. (1983). Keeping 4-H Members. Journal of Extension.

Heath, C. \& Heath, D. (2017). The power of moments: Why certain experiences have extraordinary impact. New York: Simon \& Schuster.

Kano, N. (1984). Attractive quality and must-be quality. The Journal of the Japanese Society for Quality Control, April, 39-48.

Lacanienta, A., Ellis, G., Taggart, A., Wilder, J., \& Carroll, M. (2018). Does Theming Camp Experiences Lead to Greater Quality, Satisfaction, and Promotion? Journal of Youth Development, 13, 1-2, 216-239. doi:10.5195/jyd.2018.535 
Quality of Experience

Lee, J. W., Ralston, L., Ellis, G., \& Park, J. (2011). The Influence of Nationality and Service Quality on Positive Affect, Negative Affect and Delightedness. International CHRIE Conference-Refereed Track. 9.

Lodge, M. (1981). Magnitude Scaling: Quantitative Measurement of Opinions. Beverly Hills: Sage.

Magnini, V., Crotts, J., \& Zehrer, A. (2011). Understanding customer delight: an application of travel blog analysis. Journal of Travel Research, 5O(5), 535-545. doi:10.1177\%2F0047287510379162

Mannell, R. C. \& Iso-Ahola, S. E. (1987). Psychological nature of leisure and tourism experience. Annals of Tourism Research 14(3), 314-331.

Maslow, A. (1971). Peak experiences in education and art. Theory into Practice: $A$ regeneration of the humanities. 10(3), 149-153.

Maslow, A. (2014). Toward a psychology of being. Floyd, VA: Sublime Books. (Original work published 1954.)

Maxwell, S. E., Delaney, H. D., \& Kelly, K. (2018). Designing experiments and analyzing data. (3 ${ }^{\text {rd }}$ ed.). New York: Routledge.

Matzler, K., Hinterhuber, H. H., Bailom, F., \& Sauerwein, E. (1996). How to delight your customers. Journal of Product \& Brand Management, 5(2), 6-18. doi:10.1108/10610429610119469

Morrison, M., Gan, S., Dubelaar, C., \& Oppewal, H. (2011). In-store music and aroma influences on shopper behavior and satisfaction. Journal of Business Research, 64(6), 558-564. doi:10.1016/j.jbusres.2010.06.006

Oliver, R. L. 2010. Satisfaction: A behavioral perpsective on the consumer ( $2^{\text {nd }}$ ed. $)$. M.E. Sharpe: Armonk, NY

Petrick, J. F. (2002). Development of a multi-dimensional scale for measuring the perceived value of a service. Journal of Leisure Research 34(2), 119-134. doi:10.1080/00222216.2002.11949965

Pine, B. J., \& Gilmore, J. H. (2011). The Experience Economy. Boston: Harvard Business Review Press.

Prahalad, C. K., \& Ramaswamy, V. (2004). The future of competition: Co-creating unique value with customers. Boston: Harvard Business Press.

Raykov, T. (1997). Estimation of composite reliability for congeneric measures. Applied Psychological Measurement, 21, 173-184.

Reeve, J. (2012). A Self-determination Theory Perspective on Student Engagement. In S. L. Christenson, A. L. Reschly, \& C. Wylie, Research on Student Engagement (pp. 149-172). New York: Springer Science+Business Media, LLC. doi:10.1007/978-1-4614-2018-7_7

Schneider, B., \& Bowen, D. E. (1999). Understanding customer delight and outrage. MIT Sloan Management Review, 41(1), 35-45.

Sibthorp, J. Paisley, K. \& Gookin, J. (2007). Exploring Participant Development Through Adventure-Based Programming: A Model from the National Outdoor Leadership School. Leisure Sciences, 29(1), 118. doi:10.1080/01490400600851346 
Simpkins, S. D., Little, P. M. D., \& Weiss, H. B. (2004). Understanding and measuring attendance in outof-school programs. Issues and Opportunities in Out-of-School Time Evaluation Briefs, 7, 1-12. Retrieved from: https://archive.globalfrp.org/publications-resources/browse-ourpublications/understanding-and-measuring-attendance-in-out-of-school-time-programs

Spitzer, D. R. (2007). Transforming performance measurement: Rethinking the way we measure and drive organizational success. AMACOM Books.

Stricklin, M. \& Ellis, G. D. (2018). Structuring quality experiences for event participants. Event Management. 22(3), 353-365. doi:10.3727/152599518X15251972495591

Strobel, K., Kirshner, B., O'Donoghue, J., \& McLaughlin, M. (2008). Qualities That Attract Urban Youth to After-School Settings and Promote Continued Participation. Teachers College Record, 1677-1705.

Swanson, K. K. (2004). Tourists' and retailers' perceptions of souvenirs. Journal of Vacation Marketing, 10(4), 363-377. doi:10.1177\%2F135676670401000407

Taggart, A. S. (2017). Improving point-of-service quality of youth programs through structuring the immediate experience. Unpublished masters thesis, Texas A\&M University, College Station.

Torres, E. N., \& Kline, S. (2006). From satisfaction to delight: a model for the hotel industry. International Journal of Contemporary Hospitality Management, 18(4), 290-301. doi:10.1108/09596110610665302

Torres, E. N., \& Kline, S. (2013). From customer satisfaction to customer delight: Creating a new standard of service for the hotel industry. International Journal of Contemporary Hospitality Management, 25(5), 642-659. doi:10.1108/IJCHM-Dec-2011-0228

Vesanen, J. (2007). "What is personalization? A conceptual framework." European Journal of Marketing, 41(5/6), 409-418. doi:10.1108/03090560710737534

Warrenburg, S. (2005). Effects of fragrance on emotions: moods and physiology. Chemical Senses, 30(1,1), i248-i249. doi:10.1093/chemse/bjh208

Wong, I. A. \& Cheng, M. (2012). Exploring the effects of heritage site image on souvenir shopping attitudesL the moderating role of perceived cultural difference. Journal of Travel and Tourism Marketing, 31(4), doi:10.1080/10548408.2014.883351

Zeithaml, V. A. (1988). Consumer perceptions of price, quality, and value: A means-end model and synthesis of evidence. Journal of Marketing, 52(July), 2-22. 